\title{
Procedural Sedation for Orthopedic Fracture Reductions in the Pediatric Emergency Department
}

\author{
Çocuk Acil Serviste Ortopedik Redüksiyonlarda Girişimsel Sedasyon
}

\author{
Alkan Bal1, Halim Hennes² \\ 1izmir Tepecik Training and Research Hospital, Clinic of Child Health and Diseases, Izmir, Turkey \\ 2 Texas Southwestern University Faculty of Medicine, Department of Pediatric Emergency Medicine, Dallas, Texas, USA
}

\section{Abstract}

To provide an updated literature review on pediatric procedural sedation in the emergency department. Discuss patient evaluation, monitoring, indications, and contraindications of common pharmacologic agents used for procedural sedation during orthopedic fracture reductions in the pediatric emergency department. Literature search from 1995 to 2015 was conducted using MEDLINE (PubMed), CINAHL, Cochraine and EMBASE databases. Terms included; procedural sedation, fracture reduction, orthopedic reduction, fasting, monitoring, capnometry, Bispectral index and pediatric procedural sedation. We identified a total of 1268 publications covering the literature search criteria listed above. Twenty-two studies evaluated procedural sedation for reduction of closed skeletal injuries in the pediatric emergency department (eight retrospective case series, five prospective case series and nine randomized controlled clinical trials). The published literature utilized different pain assessment scales, pharmacologic agents, and satisfaction evaluation methodology. Ketamine alone or in combination with midazolam was the most common sedation agent used in the published literature. The use of procedural sedation for performing painful procedures in the pediatric emergency department is common. Ketamine and nitrous oxide are the most commonly used pharmacologic agents. Both agents have an excellent safety profile when published sedation guidelines are followed. Patient monitoring is the single most critical element for providing safe sedation in the emergency department. There are several adjuncts for providing safe and effective sedation in the emergency department including capnography, Ramsay sedation scale, Bispectral index, and aldrete score.

Keywords: Sedation, childhood, pediatric emergency department, orthopedic reduction, capnometry, Bispectral index

\section{Öz}

Çocuk acil servisinde sık olarak uygulanan ortopedik redüksiyonlar süresince girişimsel sedasyon uygulaması ile ilgili literatürün gözden geçirilmesi ve girişimsel sedasyonda hasta seçimi, monitorizasyon ve sık kullanılan ilaçların tartışııması amaçlandı.

MEDLINE (PubMed), CINAHL, Cochraine ve EMBASE veritabanları kullanılarak 1995 ve 2015 yılları arasındaki yayınlar tarandı. Çocuk acil serviste girişimsel sedasyon uygulaması sırasında hastanın açlık durumu, monitorizasyonu, kapnometri ve Bispecteral indeks kullanımı ile ilgili ulaşılabilen 1268 makale incelendi. Literatürde çocukluk dönemindeki ortopedik redüksiyon uygulamaları ile ilgili ulaşılabilen yirmi iki makale incelendi (sekiz retrospektif olgu, beş prospektif olgu ve dokuz klinik randomize çalışma). Ketamin ve/veya midazolam kombinasyonu incelenen çalışmalarda en sık kullanılan ilaçlardı. Girişimsel sedasyon çocuk acil servislerinde sıklıkla uygulanmaktadır. Ketamin ve azot oksit girişimsel sedasyonda en yaygın kullanılan ve mevcut sedasyon rehberlerine uyularak kullanıldığında oldukça güvenli iki ilaçtır. Acil servislerde güvenli sedasyonu sağlamanın en kritik öğelerinden biri hasta monitorizasyonudur. Güvenli ve etkin sedasyonun sağlanmasında kapnografi, Ramsay sedasyon skorlaması, Bispecteral indeks ve aldrete skorlamasınıda içeren birçok etmen vardır. Çocuk acil servislerde sedasyon ile ilgili iyi planlanmış, geniş serili çalışmalara gereksinim vardır.

Anahtar Kelimeler: Sedasyon, çocukluk çağı, çocuk acil servisi, ortopedik redüksiyonlar, kapnometri, Bispectral indesk 


\section{Introduction}

Procedural sedation and analgesia (PSA) is an essential element of care for children requiring painful procedures in the pediatric emergency department (PED). While several medications are available for PSA, the ideal agent should have rapid onset of action, short recovery time, provide adequate analgesia and sedation, and have no or minimal adverse effects. To date, there is no single agent having all these properties.

Medication selection for PSA is guided by the patient's underlying medical conditions, age, anticipated degree of pain, and required procedure. To ensure patient safety during PSA, pre-sedation evaluation, American Society of Anesthesiologists (ASA) status, type of procedure, length of procedure, and monitoring equipment are important adjunct to ensure patient safety during the procedure and selecting appropriate sedation agent. 1 The safety and efficacy of PSA in the PED are well described in the literature.2,3 The objective of this review was to discuss patient evaluation and monitoring, as well as indications and contraindications of common procedural sedation (PS) pharmacologic agents properties, dose, indications, contraindications, and adverse effects during orthopedic fracture reductions in the PED.

\section{Preparing the Patient for Procedural Sedation and Analgesia}

The first step in preparing for PSA in the PED is to have dedicated staff appropriately trained in airway management, monitoring equipments, medications, and a sedation plan based on the required procedure. Requirements for safe PS are well documented in the guidelines. $4-6$ In addition to monitoring equipment, oxygen, bag-mask system, suction catheters, resuscitation medications, laryngoscope with appropriate size blades, endotracheal tubes and the other rescue airway devices should be readily available in the PSA room. 4,5

The number of personnel required to provide safe PSA is not clear. 6 However, the minimal requirement is one physician skilled in airway management to administer medication and one qualified nurse for monitoring. ${ }^{4}$ The physician responsible for sedation should not be responsible for performing the procedure.

\section{Pre-sedation Patient Evaluation}

A review of the patient allergies, medical and surgical history, and family history relevant to anesthesia is important to identify contraindication to sedation. Physical examination should include a thorough evaluation of the upper airway, including degree of mouth opening (Mallampati classification), respiratory, cardiovascular, and neurologic systems. The goal in evaluating the airway is to identify a potentially difficult airway prior to sedation (facial abnormalities, neck masses, neck mobility, obesity, etc.). The Mallampati classification is a simple scoring system to assess mouth opening and visualization of the posterior oropharynx. ${ }^{7}$ Mallampati class 3 and 4 predict a potentially difficult airway. 8 The ASA classifications categorize the health status of candidates into one of 5 classes. Patients with ASA class 1 and 2 are generally considered appropriate candidates for PSA. 4

Patient's last oral intake [nil per os (NPO) status] for PS in the emergency department (ED) remains controversial. The American Academy of Pediatrics and ASA guidelines recommendations for elective procedures are: 2 hours for clear liquids, 4 hours after breast-feeding, and 6 hours after solid and non-clear fluids.4,5 However, the association between NPO status and vomiting during or following sedation is not well established in the pediatric literature. Several observational studies found no clear association between adverse events and NPO status. ${ }^{9-12}$

\section{Monitoring}

Before initiating the PSA, baseline vital parameters (temperature, heart rate, respiratory rate, blood pressure, and pulse oximetry) should be documented. The minimal monitoring recommendation includes close patient observation by a trained provider, pulse oximetry, heart rate and intermittent assessment of the level of sedation. Monitoring in moderate and deep sedation includes continuous monitoring of oxygen saturation, heart rate, and intermittent recording of respiratory rate and blood pressure. In addition, the Ramsay sedation scale can be used to assess sedation level. ${ }^{13}$ Other noninvasive monitoring options include the use of capnography to detect hypoventilation and Bispectral index (BIS) to measure the depth of sedation (Table 1).

\section{Capnography}

There are 2 types of hypoventilation. The first one is bradycardic hypoventilation commonly observed with opioid use and characterized by increased end tidal carbon dioxide $\left(\mathrm{ETCO}_{2}\right)$ and increased partial pressure of carbon dioxide $\left(\mathrm{PaCO}_{2}\right)$. The second is hypopneic hypoventilation occurs most commonly with sedative hypnotic drugs and is characterized by a normal or decreased $\mathrm{ETCO}_{2}$ and an increased $\mathrm{PaCO}_{2}$.

Capnography is believed to detect hypoventilation during sedation before it becomes apparent by clinical examination or pulse oximetry.4,5,14 Several investigators reported early detection of hypoventilation in sedated pediatric patients when capnography is compared to conventional monitoring with pulse oximetry and patient observation. ${ }^{15-19}$ However, routine capnography use 


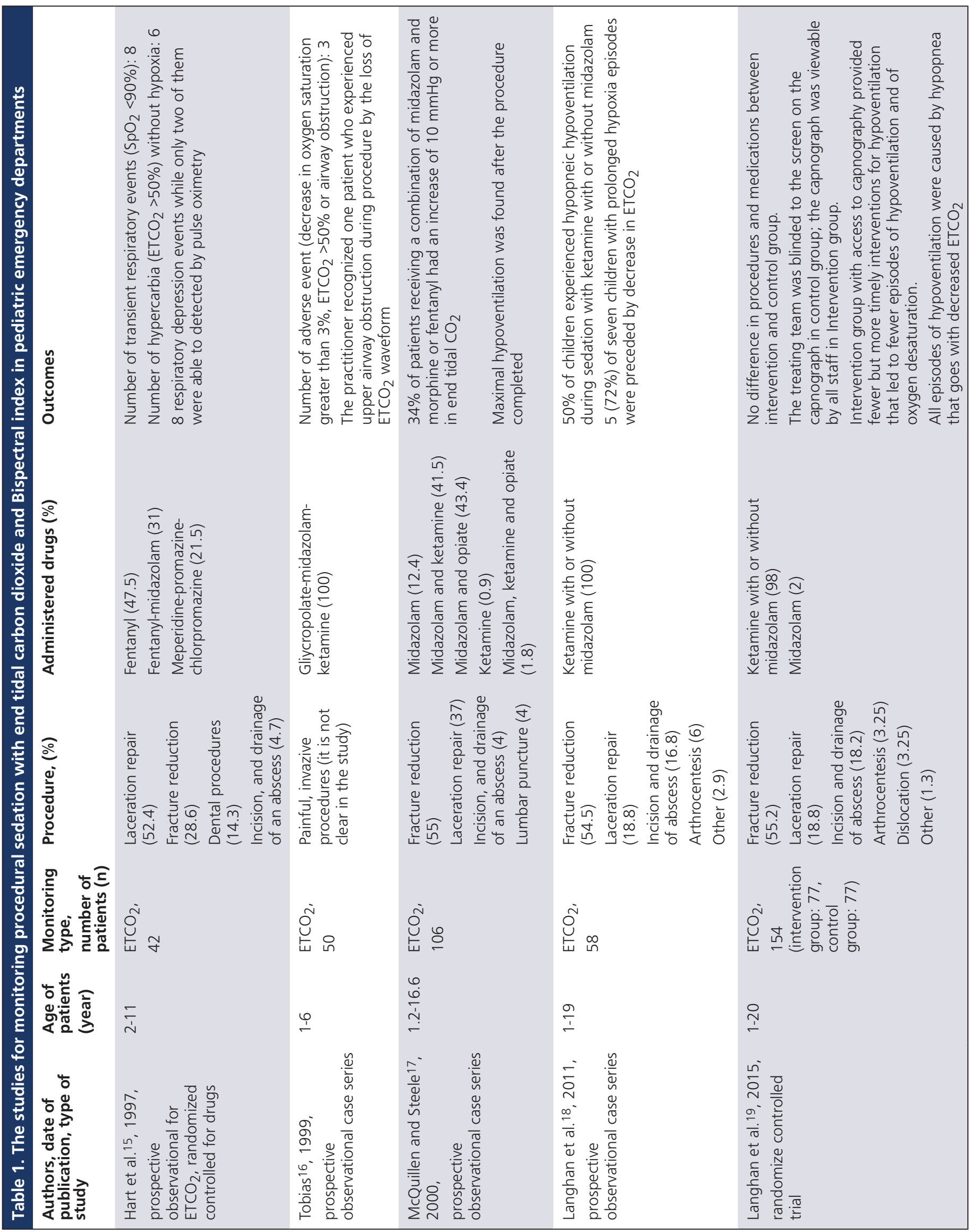




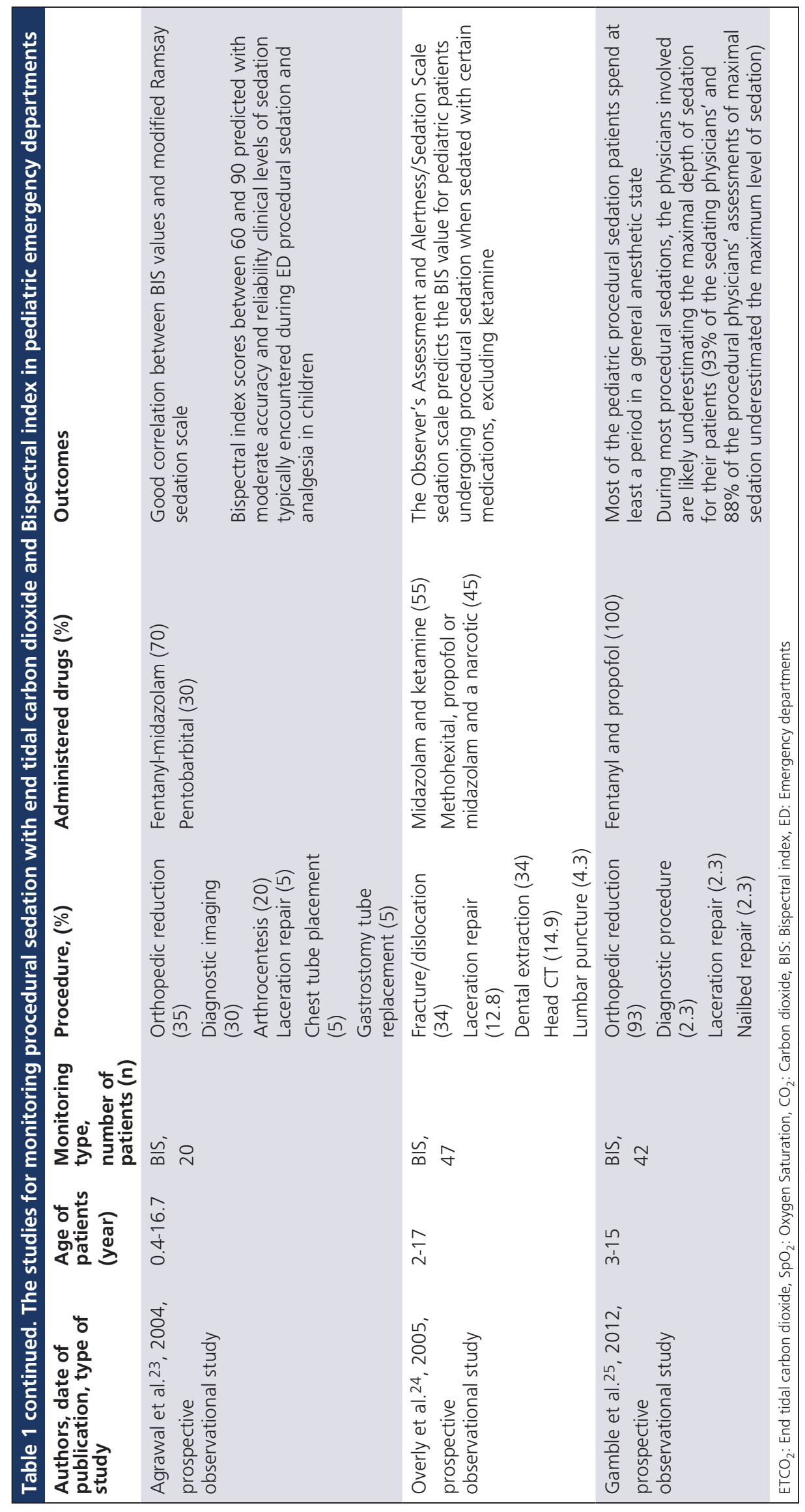

for all patients is not recommended in the current guidelines. 4,5

\section{The Bispectral Index}

The BIS is based on the principle that electroencephalography (EEG) waveforms change with the level of alertness. The index generates a numerical scale of 0-100 by placing two electrodes on the frontal-parietal areas. The BIS index is used for monitoring patients during general anesthesia to decrease the anesthetic drug dose which lead to a shorter recovery time.20 However, BIS has limited value in children receiving nitrous oxide (N2O) and infants younger than 6 months of age when sedated with ketamine. 21,22

Recent studies found a strong correlation between BIS score and modified Ramsay sedation scale.23,24 Investigators also noted poor association between the BIS and depth of sedation in patients sedated with ketamine. 24,25

\section{Common Procedural Sedation Agents Used for Fracture Reduction in Randomized Control Trials in Pediatric Emergency Departments}

Ketamine: Ketamine is a phencyclidine derivative that acts as a dissociative sedative through binding of the N-methyl-D-aspartate receptor. It provides sedation, analgesia and amnesia while preserving spontaneous breathing and protective airway reflexes. Ketamine has rapid onset of action and short half-life. Therefore, it is the preferred agent for brief painful procedures, such as fracture reduction due to its rapid onset, relatively short duration of action and excellent sedative and analgesic properties. $26-28$

The disadvantages of ketamine include vomiting, increased salivation and airway secretion, and hallucinations during recovery. A rare life-threatening complication associated with intramuscularly (IM) ketamine is 
laryngospasm. 26-30

Ketamine can be administered either IM or intravenously (IV). However, IM ketamine is associated with longer recovery time, respiratory adverse effects (especially laryngospasm) and vomiting. $29-31$

The initial ketamine dose is $1-2 \mathrm{mg} / \mathrm{kg}$ administered over 30 to 60 seconds.27,30,32,33 Chinta et al. 34 reported in a prospective small trial for fracture reduction that smaller ketamine doses $(0.7-0.8 \mathrm{mg} / \mathrm{kg})$ with a rapid infusion (5 sec) technique achieved effective brief sedation and rapid recovery.

Ketamine is the most popular agent for sedation in PED. Most studies combined it with midazolam.35-37 Investigators evaluated different combination medications including ketamine/midazolam, fentanyl/midazolam and propofol/ midazolam. 35-38 Ketamine/midazolam was found to be more effective in relieving pain and anxiety compared to fentanyl/ midazolam. 35 Favorable reduction in respiratory depression was noted with ketamine/midazolam compared to propofol midazolam. 36 The combination of propofol/fentanyl had shorter recovery and total sedation time with more desaturation than ketamine/midazolam.36-38 Midazolam premedication was associated with an increased frequency of oxygen desaturation. 39

Ketamine is contraindicated in patients younger than three months, and psychosis. History of cardiac disease and increased intracranial or intraocular pressure are relative contraindication. 32

Propofol: Propofol is a nonopioid, nonbarbiturate sedative hypnotic, first reported pediatric use for PSA in the ED was described in 1996.40 It is highly lipophilic and extensively distributed in tissues. It acts on neuronal lipid membranes to potentiate $\gamma$-aminobutyric acid effect, producing rapid sedation. 41,42

The common adverse effects of propofol are respiratory depression, apnea, bradycardia and hypotension. $42-49$ It can also cause pain during administration and injection and the recommendation is to use large vein and injecting lidocaine prior administration. 42

Because of the high lipophilic properties, unintended greater depth of sedation can occur. Propofol has several advantages over other agents, including rapid onset of action, short recovery time and reducing intracranial pressure. Several studies have examined the safety profile of propofol in the ED.45-48 Because propofol has no analgesic effect, it is often combined with an analgesic agent, opioid, which increases the potential for respiratory depression. 50

The recommended initial IV bolus dose for propofol is $0.5-1 \mathrm{mg} / \mathrm{kg}$ for brief procedures and it can be repeated every 3-5 minutes to maintain sedation to a maximum total dose $3 \mathrm{mg} / \mathrm{kg} .43,44$ In a prospective observational study, Young et al. 49 showed that $2 \mathrm{mg} / \mathrm{kg}$ initial bolus dose for pediatric sedation was well tolerated during a wide range of procedures. 45

Two randomized controlled trials evaluated the safety and efficacy of propofol for PSA during orthopedic fracture reduction in PEDs. In their study, Godambe et al.36 noted a higher event rate of respiratory depression in the propofol/ fentanyl group compared to ketamine/midazolam. Havel et al.51 found no differences in Ramsay sedation scores or complication rates between propofol/morphine and midazolam/morphine. However, they did not specifically report sedation or pain scores at the time of reduction and the study may not have enough power to detect clinically important adverse events.

Propofol formulation contains egg lecithin and soybean oil. For that reason, some authors suggest being careful when using propofol in children with allergies to these components. 52

Ketamine + Propofol (Ketofol): The combination of ketamine and propofol, known collectively as ketofol, has been used for pediatric fracture reduction for the last ten years. 53 The combination is believed to decrease the adverse effects from using either medication alone. Ketamine's sympathomimetic effect could theoretically decrease propofol-associated respiratory depression and hypotension. Propofol's sedative and anti-emetic properties could hypothetically counter the ketamine-associated recovery agitation and emesis. 41,54

No standard dosing regimen has been established; a 1:1 ratio provides ease of administration and has been documented in several recent articles.

We found one randomized controlled trial that assessed the safety and efficacy of ketofol on PSA for orthopedic reduction at PEDs. Shah et al.55 compared ketofol 1:1 and ketamine alone in 137 children for fracture reduction and found slightly faster recovery, fewer episodes of vomiting, and higher satisfaction scores in the ketofol group. 41

Another study reported shorter recovery time and 3 incidences of airway compromise requiring intervention. 56 In adult randomized controlled clinical trials, ketofol did not provide superior sedation or reduce clinically important adverse effects when compared to propofol alone.57,58

Etomidate: Etomidate is an ultrashort imidazole-derived sedative hypnotic agent with a rapid recovery time. It has rapid onset of action, short recovery time, and few side effects. Since etomidate reduces intracranial pressure and maintains hemodynamic stability, it is a better agent for patients with multisystem trauma, hypotension, and increased intracranial pressure. 26,27 


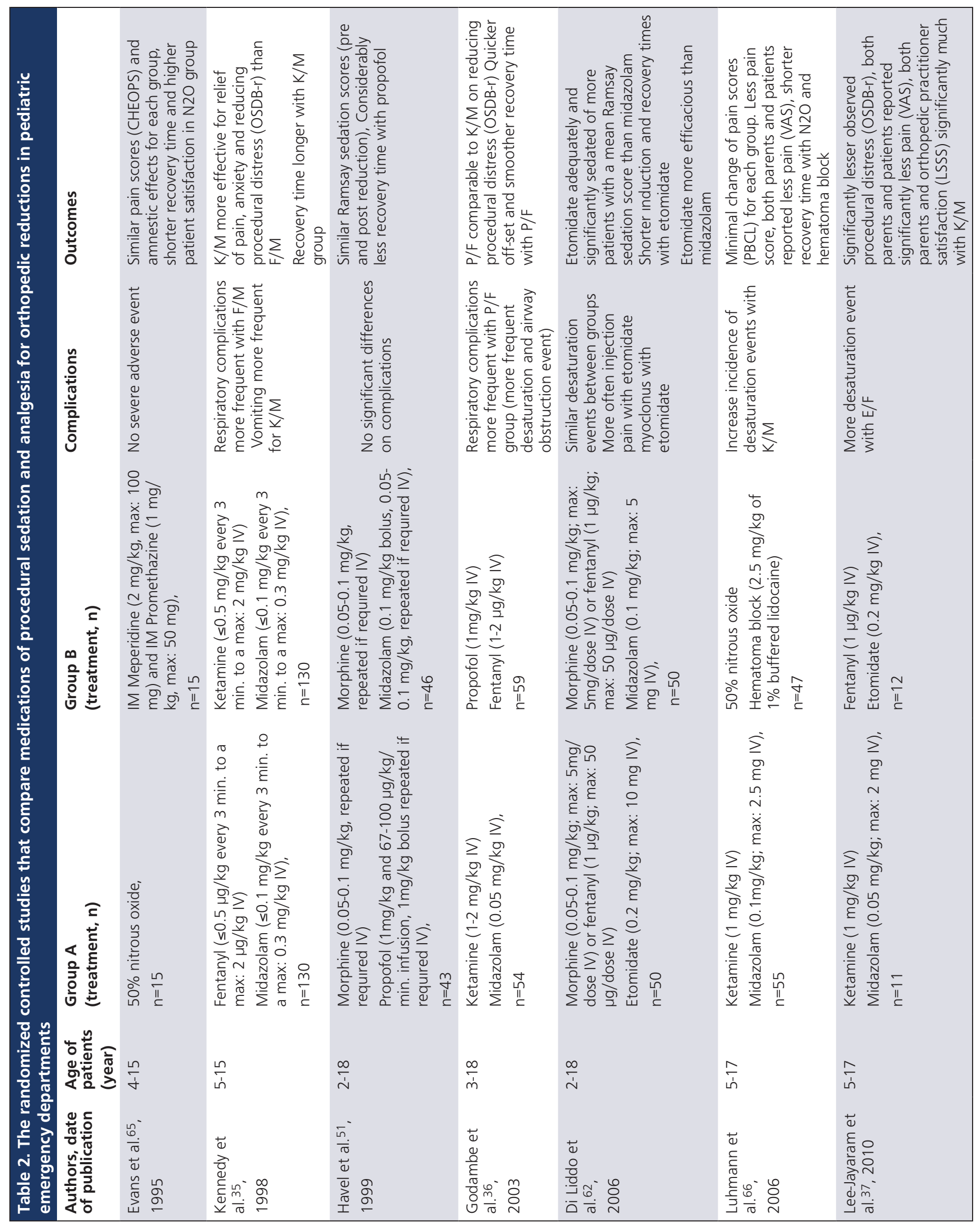




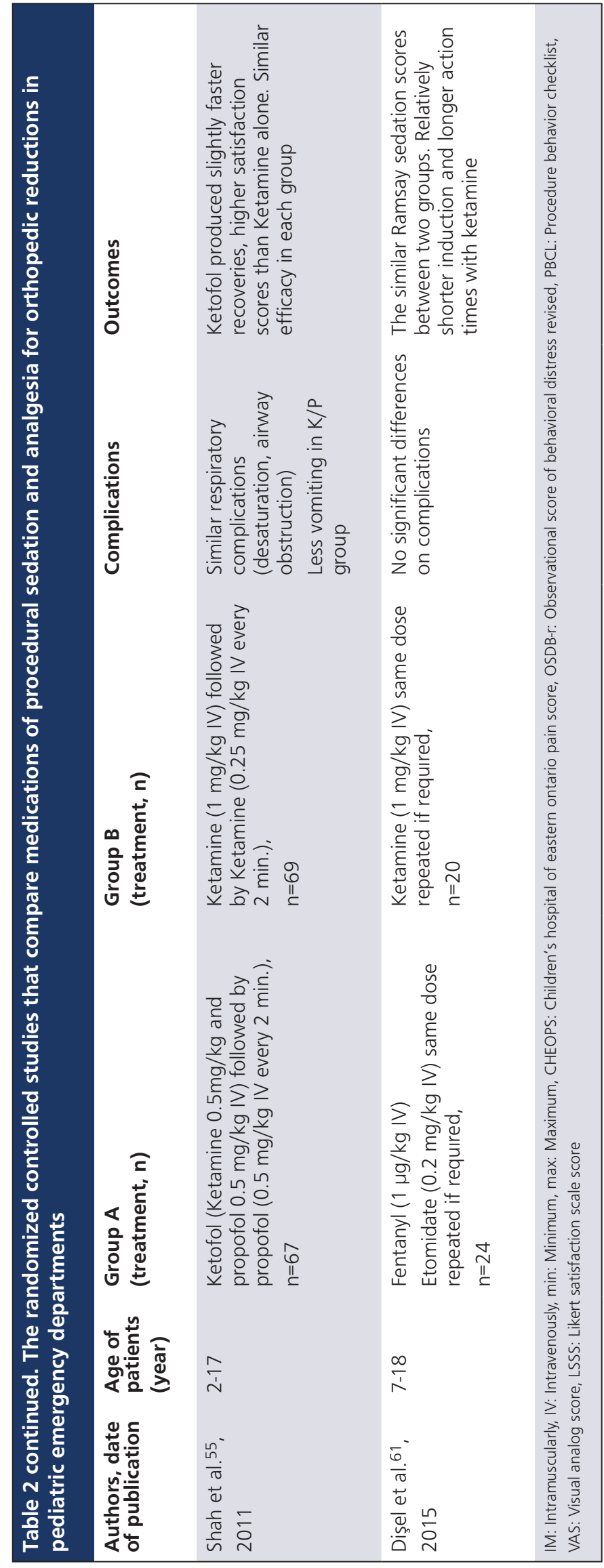

The common adverse events with etomidate are respiratory depression, vomiting and nonepileptiform myoclonus. The recommended IV bolus dose is 0.1 to $0.3 \mathrm{mg} / \mathrm{kg}$. Additional dose of $0.05 \mathrm{mg} / \mathrm{kg}$ may be given every 5 minutes up to a maximum $0.6 \mathrm{mg} / \mathrm{kg}$ total dose.26,27,59

Recent literature suggested that etomidate is a safe and effective agent for PSA.37,60,61 Liddo et al. reported that etomidate was more effective for fracture reductions with shorter induction and recovery times compared to midazolam and, similar incidence of adverse events in both groups. 62

Etomidate inhibits 11-beta hydroxylase enzyme that has an important role at adrenal steroid production pathway. It is contraindicated in adrenal insufficiency and severe sepsis. 26,27

Nitrous Oxide: $\mathrm{N}_{2} \mathrm{O}$ is a colorless anesthetic gas that provides sedation, amnesia and anxiolysis. The typically concentrations of $\mathrm{N}_{2} \mathrm{O}$ used for PSA are $50 \%$ to $70 \%$. The most common adverse effects of $\mathrm{N}_{2} \mathrm{O}$ are nausea, vomiting and dysphoria. 63,64

Two randomize controlled trials evaluated the effectiveness of $\mathrm{N}_{2} \mathrm{O}$ in comparison to other PSA drugs in orthopedic reductions. Evans et al.65 compared $50 \% \quad \mathrm{~N}_{2} \mathrm{O}$ to intramuscular meperidine and promethazine in 30 children for orthopedic fracture reduction (FR) in PED. There was no significant difference between pain scores in the two groups. However, patients in the $\mathrm{N}_{2} \mathrm{O}$ had a significantly shorter recovery time. Luhmann et al.66 compared ketamine/midazolam with $50 \% \quad \mathrm{~N}_{2} \mathrm{O}$ and a hematoma block (2.3 mg/kg of $1 \%$ buffered lidocaine) for PSA during fracture reduction of 102 children. In this study, patients who received $\mathrm{N}_{2} \mathrm{O}$ had a shorter recovery time and significantly less episodes desaturation events compared to the ketamine/midazolam group. Both parents and patients reported less pain during procedure with $\mathrm{N}_{2} \mathrm{O} .66,67$ A clinical survey on 111 pediatric emergency physicians revealed that $\mathrm{N}_{2} \mathrm{O}$ and ketamine were most commonly used in PS for FR. 68

The effect of $\mathrm{N}_{2} \mathrm{O}$ on ventilation is dose-dependent. Mechanical failure of the delivery system resulting in the delivery of $100 \% \mathrm{~N}_{2} \mathrm{O}$ is rarely associated with death. 63 Equipment must be periodically tested to ensure adequate safety. $\mathrm{N}_{2} \mathrm{O}$ is contraindicated in pneumothorax, pneumoensefalon, and bowel perforation due to its diffusion effect. Use of $\mathrm{N}_{2} \mathrm{O}$ pregnancy that increases the risk of spontaneous abortion. 26,27,63,64

In Table 2, we presented a summary of the available literature on randomize controlled trial for FR in PEDs.

Summary: Sedation and analgesia in the PED is safe and effective for common painful procedures such as closed fracture reduction. Published guidelines provide 
an excellent framework for providing safe and effective minimal to moderate sedation. When the PED physician is planning for sedation, patient safety is a top priority to avoid undesirable complications. Patient assessment, monitoring, choice of appropriate medication, and physician competence in managing potential airway compromise are essential. In choosing sedation medication, the physician should consider patient's risk factors, type of procedure, required duration to complete procedure, and medication side effects.

\section{Ethics}

Peer-review: External and Internal peer-reviewed.

\section{Authorship Contributions}

Surgical and Medical Practices: Alkan Bal, Hallim Hennes, Concept: Alkan Bal, Hallim Hennes, Design: Alkan Bal, Hallim Hennes, Data Collection or Processing: Alkan Bal, Hallim Hennes, Analysis or Interpretation: Alkan Bal, Literature Search: Alkan Bal, Hallim Hennes, Writing: Alkan Bal, Hallim Hennes.

Conflict of Interest: No conflict of interest was declared by the authors.

Financial Disclosure: The authors declared that this study received no financial support.

\section{References}

1. Connors JM, Cravero JP, Kost S, LaViolette D, Lowrie L, et al. Great expectations-defining quality in pediatric sedation: outcomes of a multidisciplinary consensus conference. J Healthc Qual. 2015;37:13954.

2. Pitetti RD, Singh S, Pierce MC. Safe and efficacious use of procedural sedation and analgesia by nonanethesiologists in a pediatric emergency department. Arch Pediatr Adolesc Med. 2003;157:10906.

3. Hertzog JH, Havidich JE. Non-anesthesiologist-provided pediatric procedural sedation: an update. Curr Opin Anaesthesiol 2007;20:365-72.

4. American Academy of Pediatrics; American Academy of Pediatric Dentistry, Coté CJ, Wilson S; Work Group on Sedation. Guidelines for monitoring and management of pediatric patients during and after sedation for diagnostic and therapeutic procedures: an update. Pediatrics. 2006;118:2587-602.

5. American Society of Anesthesiologists Task Force on Sedation and Analgesia by Non-Anesthesiologists. Practice guidelines for sedation and analgesia by non-anesthesiologists. Anesthesiology. 2002:96:1004-17

6. Godwin SA, Caro DA, Wolf SJ, Jagoda AS, Charles R, et al. Clinical policy: procedural sedation and analgesia in the emergency department. Ann Emerg Med. 2005;45:177-96.

7. Samsoon GL, Young JR. Difficult tracheal intubation: a retrospective study. Anaesthesia. 1987;42:487-90.

8. Heinrich S, Birkholz T, Ihmsen H, Irouschek A, Ackermann A, et al. Incidence and predictors of difficult laryngoscopy in 11,219 pediatric anesthesia procedures. Paediatr Anaesth. 2012;22:729-36.
9. Agrawal D, Manzi SF, Gupta R, Krauss B. Preprocedural fasting state and adverse events in children undergoing procedural sedation and analgesia in a pediatric emergency department. Ann Emerg Med. 2003;42:636-46

10. Babl FE, Puspitadewi A, Barnett P, Oakley E, Spicer M. Preprocedural fasting state and adverse events in children receiving nitrous oxide for procedural sedation and analgesia. Pediatr Emerg Care. 2005;21:736-43.

11. Roback MG, Bajaj L, Wathen JE, Bothner J. Preprocedural fasting and adverse events in procedural sedation and analgesia in a pediatric emergency department: are they related? Ann Emerg Med. 2004;44:454-9.

12. Pasarón R, Burnweit C, Zerpa J, Malvezzi L, Knight C, et al. Nitrous oxide procedural sedation in non-fasting pediatric patients undergoing minor surgery: a 12-year experience with 1,058 patients. Pediatr Surg Int. 2015;31:173-80.

13. Sessler CN, Grap MJ, Ramsay MA. Evaluating and monitoring analgesia and sedation in the intensive care unit. Crit Care. 2008;12(Suppl 3):2.

14. Sammartino M, Volpe B, Sbaraglia F, Garra R, D'Addessi A. Capnography and the bispectral index-their role in pediatric sedation: a brief review. Int J Pediatr. 2010;2010:828347.

15. Hart LS, Berns SD, Houck CS, Boenning DA. The value of end-tidal $\mathrm{CO} 2$ monitoring when comparing three methods of conscious sedation for children undergoing painful procedures in the emergency department. Pediatr Emerg Care. 1997;13:189-93.

16. Tobias JD. End-tidal carbon dioxide monitoring during sedation with a combination of midazolam and ketamine for children undergoing painful, invasive procedures. Pediatr Emerg Care. 1999;15:173-75.

17. McQuillen KK, Steele DW. Capnography during sedation/analgesia in the pediatric emergency department. Pediatr Emerg Care. 2000;16:401-4.

18. Langhan ML, Chen L, Marshall C, Santucci KA. Detection of hypoventilation by capnography and its association with hypoxia in children undergoing sedation with ketamine. Pediatr Emerg Care. 2011;27:394-7.

19. Langhan ML, Shabanova V, Li FY, Bernstein SL, Shapiro ED. A randomized controlled trial of capnography during sedation in a pediatric emergency setting. Am J Emerg Med. 2015;33:25-30.

20. Punjasawadwong $Y$, Phongchiewboon A, Bunchungmongkol N. Bispectral index for improving anaesthetic delivery and postoperative recovery. Cochrane Database of Syst Rev. 2014;6:CD003843.

21. Barr GA, Jakobsson JG, Wall AO, Anderson RE. Nitrous oxide does not alter bispectral index: study with nitrous oxide as sole agent and as an adjunct to i.v. anaesthesia. Br J Anaesth. 1999;82:827-830.

22. Malviya S, Voepel-Lewis T, Tait AR, Watcha MF, Sadhasivam S, et al. Effect of age and sedative agent on the accuracy of bispectral index in detecting depth of sedation in children. Pediatrics. 2007;120:46170.

23. Agrawal D, Feldman HA, Krauss B, Waltzman ML. Bispectral index monitoring quantifies depth of sedation during emergency department procedural sedation and analgesia in children. Ann Emerg Med. 2004;43:247-55.

24. Overly FL, Wright RO, Connor FA Jr, Fontaine B, Jay G, et al. Bispectral analysis during pediatric procedural sedation. Pediatr Emerg Care. 2005;21:6-11.

25. Gamble C, Gamble J, Seal R, Wright RB, Ali S. Bispectral analysis during procedural sedation in the pediatric emergency department. Pediatr Emerg Care. 2012;28:1003-8. 
26. Krauss B, Green SM. Procedural sedation and analgesia in children. Lancet. 2006;367:766-80.

27. Sahyoun C, Krauss B. Clinical implications of pharmacokinetics and pharmacodynamics of procedural sedation agents in children. Curr Opin Pediatr. 2012;24:225-32.

28. Green SM, Krauss B. Clinical practice guideline for emergency department ketamine dissociative sedation in children. Ann Emerg Med. 2004;44:460-71.

29. Melendez E, Bachur R. Serious adverse events during procedural sedation with ketamine. Pediatr Emerg Care. 2009;25:325-8.

30. Green SM, Roback MG, Krauss B, Brown L, McGlone RG, et al. Predictors of emesis and recovery agitation with emergency department ketamine sedation: an individual-patient data metaanalysis of 8,282 children. Ann Emerg Med. 2009;54:171-80.

31. Roback MG, Wathen JE, MacKenzie T, Bajaj L. A randomized, controlled trial of i.v. versus i.m. ketamine for sedation of pediatric patients receiving emergency department orthopedic procedures. Ann Emerg Med. 2006;48:605-12.

32. Green SM, Roback MG, Kennedy RM, Kraus B. Clinical practice guideline for emergency department ketamine dissociative sedation: 2011 update. Ann Emerg Med. 2011;57:449-61.

33. Heilbrunn BR, Chang TP, Liu DR. A retrospective comparison of ketamine dosing regimens for pediatric procedural sedation. Eur J Emerg Med. 2015;22:111-6.

34. Chinta SS, Schrock CR, McAllister JD, Jaffe DM, Liu J, et al. Rapid administration technique of ketamine for pediatric forearm fracture reduction: a dose-finding study. Ann Emerg Med. 2015;65:640-8.

35. Kennedy RM, Porter FL, Miller JP, Jaffe DM. Comparison of fentanyl/ midazolam with ketamine/midazolam for pediatric orthopedic emergencies. Pediatrics. 1998;102:956-63

36. Godambe SA, Elliot V, Matheny D, Pershad J. Comparison of propofol/fentanyl versus ketamine/midazolam for brief orthopedic procedural sedation in a pediatric emergency department. Pediatrics. 2003; 112:116-23

37. Lee-Jayaram JJ, Green A, Siembieda J, Gracely EJ, Mull CC, et al. Ketamine/midazolam versus etomidate/fentanyl: procedural sedation for pediatric orthopedic reductions. Pediatr Emerg Care. 2010;26:408-12.

38. Langston WT, Wathen JE, Roback MG, Bajaj L. Effect of ondansetron on the incidence of vomiting associated with ketamine sedation in children: a double-blind, randomized, placebo-controlled trial. Ann Emerg Med. 2008;52:30-4.

39. Wathen JE, Roback MG, Mackenzie T, Bothner JP. Does midazolam alter the clinical effects of intravenous ketamine sedation in children? A double-blind, randomized, controlled, emergency department trial. Ann Emerg Med. 2000;36:579-88.

40. Swanson ER, Seaberg DC, Mathias S. The use of propofol for sedation in the emergency department. Acad Emerg Med. 1996;3:234-8.

41. Alletag MJ, Auerbach MA, Baum CR. Ketamine, propofol, and ketofol use for pediatric sedation. Pediatr Emerg Care. 2012;28:1396-8.

42. Barnett P. Propofol for pediatric sedation. Pediatr Emerg Care. 2005;21:111-4.

43. Fein JA, Selbst SM. Sedation and analgesia. In: Fleisher GR, Ludwig S, (eds). Textbook of Pediatric Emergency Medicine. 6th ed. Philadelphia, PA: Wolters Kluwer/Lippincott Williams \& Wilkins Health; 2010:58-73.

44. Miner JR, Burton JH. Clinical practice advisory: Emergency department procedural sedation with propofol. Ann Emerg Med. 2007;50:182-7.
45. Bassett KE, Anderson JL, Pribble CG, Guenther E. Propofol for procedural sedation in children in the emergency department. Ann Emerg Med. 2003;42:773-82.

46. Guenther E, Pribble CG, Junkins EP Jr, Kadish HA, Bassett KE, et al. Propofol sedation by emergency physicians for elective pediatric outpatient procedures. Ann Emerg Med. 2003;42:783-91.

47. Pershad J, Godambe SA. Propofol for procedural sedation in the pediatric emergency department. J EmergMed. 2004;27:11-4.

48. Mallory MD, Baxter AL, Yanosky DJ, Cravero JP; Pediatric Sedation Research Consortium. Emergency physician-administered propofol sedation: a report on 25,433 sedations from the pediatric sedation research consortium. Ann Emerg Med. 2011;57:462-8.

49. Young TP, Lim JJ, Kim TY, Thorp AW, Brown L. Pediatric procedural sedation with propofol using a higher initial bolus dose. Pediatr Emerg Care. 2014;30:689-93.

50. Miner JR, Gray RO, Stephens D, Biros MH. Randomized clinical trial of propofol with and without alfentanil for deep procedural sedation in the emergency department. Acad Emerg Med. 2009;16:825-34.

51. Havel CJ Jr, Strait RT, Hennes H. A clinical trial of propofol vs midazolam for procedural sedation in a pediatric emergency department. Acad Emerg Med. 1999;6:989-97.

52. Hofer KN, McCarthy MW, Buck ML, Hendrick AE. Possible anaphylaxis after propofol in a child with food allergy. Ann Pharmacother. 2003;37:398-401.

53. Sharieff GQ, Trocinski DR, Kanegaye JT, Fisher B, Harley JR. Ketaminepropofol combination sedation for fracture reduction in the pediatric emergency department. Pediatr Emerg Care. 2007;23:881-4.

54. Green SM, Andolfatto G, Krauss BS. Ketofol for procedural sedation revisited: pro and con. Ann Emerg Med. 2015;65:489-91.

55. Shah A, Mosdossy G, McLeod S, Lehnhardt K, Peddle M, et al. A blinded, randomized controlled trial to evaluate ketamine-propofol versus ketamine alone for procedural sedation in children. Ann Emerg Med. 2011;57:425-33.

56. Andolfatto G, Willman E. A prospective case series of pediatric procedural sedation and analgesia in the emergency department using single-syringe ketamine-propofol combination (ketofol). Acad Emerg Med. 2010;17:194-201.

57. Andolfatto G, Abu-Laban RB, Zed PJ, Staniforth SM, Stackhouse $S$, et al. Ketamine-propofol combination (ketofol) versus propofol alone for emergency department procedural sedation and analgesia: a randomized double-blind trial. Ann Emerg Med. 2012;59:504-12.

58. Miner JR, Moore JC, Austad EJ, Plummer D, Hubbard L, et al. Randomized, double-blinded clinical trial of propofol, 1:1 propofol/ ketamine, and 4:1 propofol/ketamine for deep procedural sedation in the emergency department. Ann Emerg Med. 2015;65:479-88.

59. Kost S, Roy A. Procedural sedation and analgesia in the pediatric emergency department: a review of sedative pharmacology. Clin Pediatr Emerg Med. 2010;11:233-43.

60. Dickinson R, Singer AJ, Carrion W. Etomidate for pediatric sedation prior to fracture reduction. Acad Emerg Med. 2001;8:74-7.

61. Dişel NR, Yilmaz HL, Sertdemir Y, Yeşilağaç $H$, Avci A. Etomidate Versus Ketamine: Effective Use in Emergency Procedural Sedation for Pediatric Orthopedic Injuries. Pediatr Emerg Care. 2015 Apr 1. [Epub ahead of print]

62. Di Liddo L, D'Angelo A, Nguyen B, Bailey B, Amre D, et al. Etomidate versus midazolam for procedural sedation in pediatric outpatients: a randomized controlled trial. Ann Emerg Med. 2006;48:433-40. 
63. Mace SE, Brown LA, Francis L, Godwin SA, Hahn SA, et al. Clinical policy: Critical issues in the sedation of pediatric patients in the emergency department. Ann Emerg Med. 2008;51:378 99.

64. Tobias JD. Applications of nitrous oxide for procedural sedation in the pediatric population. Pediatr Emerg Care. 2013;29:24565.

65. Evans JK, Buckley SL, Alexander AH, Gilpin AT. Analgesia for the reduction of fractures in children: a comparison of nitrous oxide with intramuscular sedation. J Pediatr Orthop. 1995;15:73-7.
66. Luhmann JD, Schootman M, Luhmann SJ, Kennedy RM. A randomized comparison of nitrous oxide plus hematoma block versus ketamine plus midazolam for emergency department forearm fracture reduction in children. Pediatrics. 2006;118:1078-86.

67. Srinivasan M, Carlson DW. Procedural sedation by pediatric hospitalists: analysis of the nature and incidence of complications during ketamine and nitrousoxide sedation. Hosp Pediatr. 2013;3:342-7.

68. Schofield S, Schutz J, Babl FE; Paediatric Research in Emergency Departments International Collaborative (PREDICT. Procedural sedation and analgesia for reduction of distal forearm fractures in the paediatric emergency department: a clinicalsurvey. Emerg Med Australas. 2013;25: 241-7. 